\title{
MANIPULATING THE PRODUCTION OF MONO-SEX NILE TILAPIA, OREOCHROMIS NILOTICUS, FRY THROUGH WINTER SEASON
}

\author{
W.M.A. Fayed \\ Department of Animal and Fish Production, Faculty of Agriculture (Saba Basha), 22 Tag Al Roasaa \\ st., saba-basha, boulkly, Alexandria University, Alexandria, Egypt. \\ Corresponding author: fayedwal@gmail.com
}

(Received 1/10/2015, Accepted 29/11/2015)

\section{SUMMARY}

$\mathrm{T}$ he influence of low temperature on survival rate and growth performance were compared on native fry of mono-sex Oreochromis niloticus to determine how winter season affects the final biomass and production of fry in Egypt. Six diets containing three protein (30, 35, and 40\%) and two energy (370 and $470 \mathrm{kcal} \mathrm{ME} / 100 \mathrm{~g}$ ) levels were offered to fry $(1.03 \mathrm{~g}$ ) to satiation, twice daily, for 6 months. At all protein levels, fry fed low-energy diets $(370 \mathrm{kcal} \mathrm{ME} / 100 \mathrm{~g})$ revealed poor growth and feed conversion efficiency, survival rates, compared to those fed high-energy (470 kcal ME/100g) diets. At dietary protein levels from 35 to $40 \%$ crude protein (CP), fish growth and survival rates were significantly improved by increasing dietary energy from 370 to $470 \mathrm{kcal}(\mathrm{ME} / 100 \mathrm{~g}$ diet). However, the best growth rate and feed utilization were obtained with $40 \% \mathrm{CP}$ and $470 \mathrm{kcal}(\mathrm{ME} / 100 \mathrm{~g}$ diet). Body composition was significantly affected by both dietary protein and energy levels. As such, to overcome the low winter season temperatures the $O$. niloticus fry requires $40 \% \mathrm{CP}$ and $470 \mathrm{kcal}(\mathrm{ME} / 100 \mathrm{~g} \mathrm{diet})$ for maximum growth and best survival rate when reared in earthen ponds in Egypt.

Keywords: Mono-sex, Nile tilapia fry, cold tolerance, growth performance, temperature, winter season, production, Oreochromis niloticus.

\section{INTRODUCTION}

Stress in farmed fish is of considerable significance to both health and productivity as it has been linked to reduction in growth, abnormal behavior, and immune suppression (Ashley 2007). Many exogenous factors have contributed in widespread of tilapia global growth due to its rapid compliant to wide range of environmental conditions (Mjoun et al., 2010). Nile tilapia, Oreochromis niloticus (L.), is one of the most preferable cultured species due to its high growth rate, substantial tolerance to environmental stressors (Ballarin and Haller, 1982), spontaneity of reproduction, and high market demand (El-Sayed 2006a). Water temperature is one of several aspects that triggers the onset of gonadal maturation, spawning, and spawning frequency of tilapia reproduction (Philippart and Ruwet, 1982), and a major metabolic modifier (Mjoun et al, 2010). Water temperature at which mortality begins should be highly considered in terms of cold tolerance in commercial tilapia production. However, optimal growing and spawning temperatures are typically between $22^{\circ} \mathrm{C}$ and $29^{\circ} \mathrm{C}$ (Caulton, 1982). Most tilapia species are unable to survive at temperatures below $10^{\circ} \mathrm{C}$ (Chervinski, 1982), and growth is poor below $20^{\circ} \mathrm{C}$ (Mires, 1995). Despite of water temperature, tilapia was found to tolerate an expandable range of environmental conditions including dissolved oxygen (Ross, 2000), salinity (El-Sayed 2006b), pH (Ross, 2000), and ammonia levels (El-Sherif et al., 2008), compared to other cultured freshwater fishes. The low trophic level of tilapia and being an omnivorous type of fish tolerating high dietary fiber and carbohydrate concentration makes them inexpensive to feed (El-Sayed 2006a). Throughout its life stages, tilapia feed on a wide variety of dietary sources such as phytoplankton, periphyton, zooplanktons, larval fish, and detritus. A well balanced formulated feeds is required in tilapia culture to guarantee fast growth and high 
yield. However, the nutritional requirements of tilapia varies among species and are mainly affected by age, size and stage (Al Hafedh, 1999). Fish uses dietary proteins for maintenance, growth, and reproduction. Jauncey (2000) suggested that to maximize protein utilization, dietary lipid concentration should be between 8 and $12 \%$ for tilapia up to $25 \mathrm{~g}$, and 6 to $8 \%$ for larger fish. Therefore, the profile of dietary protein is important when formulating diets for tilapia. In Egypt, seasonal low temperatures creates a critical problem for tilapia culture and seed production. As water temperature drops between $9^{\circ} \mathrm{C}$ and $15^{\circ} \mathrm{C}$ causes reduction in breeding activities, and high mortality rates, especially in shallow ponds. Favorable temperature range for raising Nile tilapia are from $25^{\circ} \mathrm{C}$ to $35^{\circ} \mathrm{C}$, which is between April and December (Dan and Little, 2000). However, natural spawning only begins in April, and seeds are not normally available until June-July, reducing the duration of the production season (Shamsuddin et al., 2012). Besides, the lack of a reliable supply of fry has been an important constraint and a limiting factor in poorly established or limited financed infrastructure. Thus, self-sufficiency of fry production has been found to be necessary for the success of Nile tilapia culture between small-scale farmers. Overwintering of late-spawned tilapia fry may be a possible way to make fingerlings available early in the following grow-out season. Long winters and low temperature has been reported to have negative effects on tilapia production in China whereas the production have dropped by as much as $80 \%$ as estimated by observers (Globelfish 2008). In many countries, overwintering of tilapia fry has been successfully conducted in heated facilities (Behrends et al., 1990) or underground warm water (Cruz and Ridha, 1994) and in green houses (Jiazhao, 1991), but these resources are scarce and could be unavailable in Egypt. In general, production systems would probably not be economically sustainable if mortality rates because of low temperature exceed 10\% (Patricio, 2004). The general consensus is that to decrease costs mortality should be reduced and growth of Nile tilapia should be prolonged, and thus enhancing the tolerance to low temperature is an important target (Kamel et al., 2008). Therefore, the main objective of the present study is to enhance the survival and growth performance of $O$. niloticus fry through winter season using dietary protein and energy levels, to make fingerlings available early in the following grow-out season.

\section{MATERIALS AND METHODS}

The present study was conducted for six months, from October through March, on mono-sex $O$. niloticus fry with an average initial body weight of $1.03 \mathrm{~g} / \mathrm{fry}$. Fry were treated with $17 \alpha$ methyletestesterone after hatching for 21 day. Fry requirements for protein and energy was configured in the present study to attain the maximum production through the winter season. Fry were fed daily on formulated experimental diets (Table 1) to ad-libitum three times a day 7days/week. Three protein levels $(30 \%, 35 \%$ and $40 \%, \mathrm{CP})$ were tested at two energy levels (370 and $470 \mathrm{kcal} \mathrm{ME} / 100 \mathrm{~g}$ diet) forming six practical diets embracing a $(3 \times 2)$ factorial design experimental treatments (Table 1). Each treatment in the present study had two replicates. Water samples were taken monthly for water quality analysis, also fish samples were spared at the beginning and end of the experiment for carcass composition analysis.

Table (1). Ingredients composition and chemical analysis (dry matter) of experimental diets used for mono-sex $O$. niloticus in the present study.

\begin{tabular}{lcccccc}
\hline Protein levels\% & \multicolumn{2}{c}{$30 \%$} & \multicolumn{3}{c}{$35 \%$} & $40 \%$ \\
\cline { 2 - 7 } Energy Kcal/100g & 370 & 470 & 370 & 470 & 370 & 470 \\
\hline Fish meal & 150 & 150 & 200 & 200 & 250 & 250 \\
Soybean & 150 & 150 & 200 & 200 & 250 & 250 \\
Shrimp meal & 150 & 150 & 150 & 150 & 150 & 150 \\
Wheat bran & 400 & 400 & 320 & 300 & 250 & 200 \\
Cod liver oil & 10 & 60 & 10 & 60 & 10 & 60 \\
Corn oil & 10 & 60 & 10 & 60 & 10 & 60 \\
Vitamin \& mineral & 30 & 30 & 30 & 30 & 30 & 30 \\
Cellulose & 100 & 0 & 80 & 0 & 50 & 0 \\
Chemical analysis & & & & & & 38.38 \\
Crude protein & 29.87 & 29.87 & 33.96 & 33.62 & 38.71 & 15.56 \\
Lipids & 6.92 & 16.32 & 5.47 & 15.89 & 5.64 & 26.12 \\
NFE & 34.74 & 35.73 & 31.15 & 31.54 & 26.36 & 470 \\
Gross energy & 370 & 470 & 370 & 470 & 370 & \\
\hline
\end{tabular}


Stocking density:

Twelve-indoor concrete tanks (water volume of $1 \mathrm{~m}^{3} / \mathrm{tank}$ ) with dimensions $(0.75 \mathrm{~m} \times 1 \mathrm{~m} \times 2 \mathrm{~m})$ were used in the first 45 days for stocking O. niloticus fry (1000 fry/tank). After the 45 days fry were transferred to earthen pond $\left(200 \mathrm{~m}^{3}\right)$ with stocking rate of $500 \mathrm{fry} / \mathrm{m}^{3}$ bringing a total of 10,000 fry/pond.

\section{Fish growth and feed utilization parameters:}

Growth performance and feed utilization of Nile tilapia was determined, and was calculated as follows:

Specific growth rate (SGR) (in percent per day) $=\frac{100\left(\mathrm{LnW}_{2}-\mathrm{LnW}_{1}\right)}{\mathrm{T}}$

Where W1 and W2 are the initial and the final weights, respectively, and $\mathrm{T}$ is the number of days of the experiment;

Feed conversion ratio $(\mathrm{FCR})=\frac{\text { feed intake(in grams) }}{\text { weight gain (in grams) }}$

Protein efficiency ratio (PER) $=\frac{\text { weight gain (in grams) }}{\text { protein intake (in grams) }}$

Protein productive value (PPV) (in percent) $=100\left[\frac{\text { protein gain (in grams) }}{\text { protein intake (in grams) }}\right]$

\section{Proximate analysis:}

Specimen of mono-sex $O$. niloticus fry from each treatment were spared frozen for final body composition analysis. Fish samples were randomly taken at the beginning and end of the experiments. Samples of fish diets were stored at $\left(-18^{\circ} \mathrm{C}\right)$ until proximate analysis. All chemical analyses for fish and diets (Table 1) were determined according to standard methods of (AOAC, 2000).

\section{Statistical analysis:}

Results of growth parameters, feed utilization parameters, body carcasses composition, and survival rate $(\%)$ of fry of the experimental treatments were treated using the ANOVA test (analysis of variance) and Tuckey test to a minimum significance $(\mathrm{P}<0.05)$. The results are expressed as means \pm SEM. Statistical analysis was performed using two-way ANOVA according to Assaad et al. (2014) and EXCEL (windows 10, 2015). Graphs has been performed using SigmaPlot for windows (Systat Software, Inc., version 12.0, 2011).

\section{RESULTS AND DISCUSSION}

Growth of tilapia in Egypt is constrained by cold winter seasons, during which significant mortalities occurs in commercial fish farms leading up to great losses in the production and income. However, cold tolerance trait in some tilapia species could be of great economic importance in temperate countries, when sever cold winter seasons causes high mortalities (Hsieh et al., 2007; Williams and Dasgupta, 2007). The most significant of the low temperature days in the study herein is during the night where temperatures drops critically sometimes below $8^{\circ} \mathrm{C}$. Accordingly, the water temperatures of the experimental ponds in the present study was greatly influenced with the daily variation in weather temperature. Presumably, Likongwe et al. (1996) stated that temperature of shallow and small pieces of water bodies might follow air temperature. It has also been reported by Charo-Karisa et al. (2005) that tilapia reared under midsummer conditions died between $13.6^{\circ} \mathrm{C}$ and $8.6^{\circ} \mathrm{C}$, while those reared under autumn condition died between $11.7^{\circ} \mathrm{C}$ and $7.5^{\circ} \mathrm{C}$. In the present study, the effect of low winter season temperature on fry of mono-sex $O$. niloticus on ADG and ADG\% was observed from mid of December through end of January 
even by suppling it with different protein and energy diets. In the study herein, the temperatures had reached as low as $8-9^{\circ} \mathrm{C}$ during some nights of the month of January. After six months of experimental trial the results demonstrated that the final body weight (FBW) (Table 2 and figure 1) and weight gain $(\mathrm{WG})$ of fry significantly increased $(\mathrm{P}<0.05)$ with diets encompassed protein and energy levels of 35\%CP; ME $470 \mathrm{Kcal} / 100 \mathrm{~g}$ and 40\% CP; ME 370 and $470 \mathrm{Kcal} / 100 \mathrm{~g}$ (Table 2). The significantly least FBW and WG was observed on fry with diet contained 30\% CP and ME $370 \mathrm{Kcal} / 100 \mathrm{~g}$. Dan and Little (2000) compared large $(>1 \mathrm{~g})$ and small $(<1 \mathrm{~g})$ tilapia fry to be over-wintered in deep hapas-in-ponds, and observed that survival rate of larger mono-sex tilapia fry was $54 \%$, which was significantly higher than that of smaller fry $(33.4 \%)$. This corresponds with the IBW of the experimented mono-sex fry of the present study $(1.03 \mathrm{~g})$ to be overwintered for the next production season. However, fry that had the highest FBW and WG in the present study reached survival of (66\%) compared to those lower in FBW and WG (41\%). This coincides with the results reported by Charo-Karisa et al. (2005) who reported that fish body weight had a highly significant effect on cold tolerance. Moreover, Charo-Karisa et al. (2005) stated that the most appropriate way of enhancing cold tolerance of tilapia juveniles is by husbandry practices that increase pre-winter body weights. The average daily gain (ADG g/fish/day, and ADG \%) fluctuated significantly $(\mathrm{P}<0.05)$ between all treatments from 0.09 to $0.15 \mathrm{~g} / \mathrm{fry} / \mathrm{day}$ (Table 2$)$. The highest was recorded for fry fed $35 \% \mathrm{CP}$; ME $470 \mathrm{Kcal} / 100 \mathrm{~g}$ diet, and the least ADG was for $30 \% \mathrm{CP}$; $370 \mathrm{Kcal}$ $\mathrm{ME} / 100 \mathrm{~g}$ diet. In the same manner, Fayed (2014) implied that the growth rate of mono-sex O. niloticus represented by FBW, WG, and ADG was increased significantly $(\mathrm{P}<0.01)$ with the increase of dietary protein levels. However, Fayed et al. (2015) found that feeding O. niloticus broodstocks on diets containing not less than $30 \% \mathrm{CP}$ during pre-spawning period enhanced weight gain and number of produced fry viability on tolerating low winter season temperature compared to broodstocks fed low dietary protein levels. Siddik et al. (2014) stated that culture of mono-sex tilapia during winter is more profitable due to its higher growth rate. Also, Siddik et al. (2014) implied that six months over-wintered culture of mixed sex and mono-sex tilapia showed that the growth of mono-sex tilapia was significantly $32 \%$ higher than of mixed-sex tilapia. Whereas, Lovshin et al. (1990) demonstrated that all male fish grew $121 \%$ and $69 \%$ larger than those in populations containing $2.5 \%$ and $5.0 \%$ females, respectively.

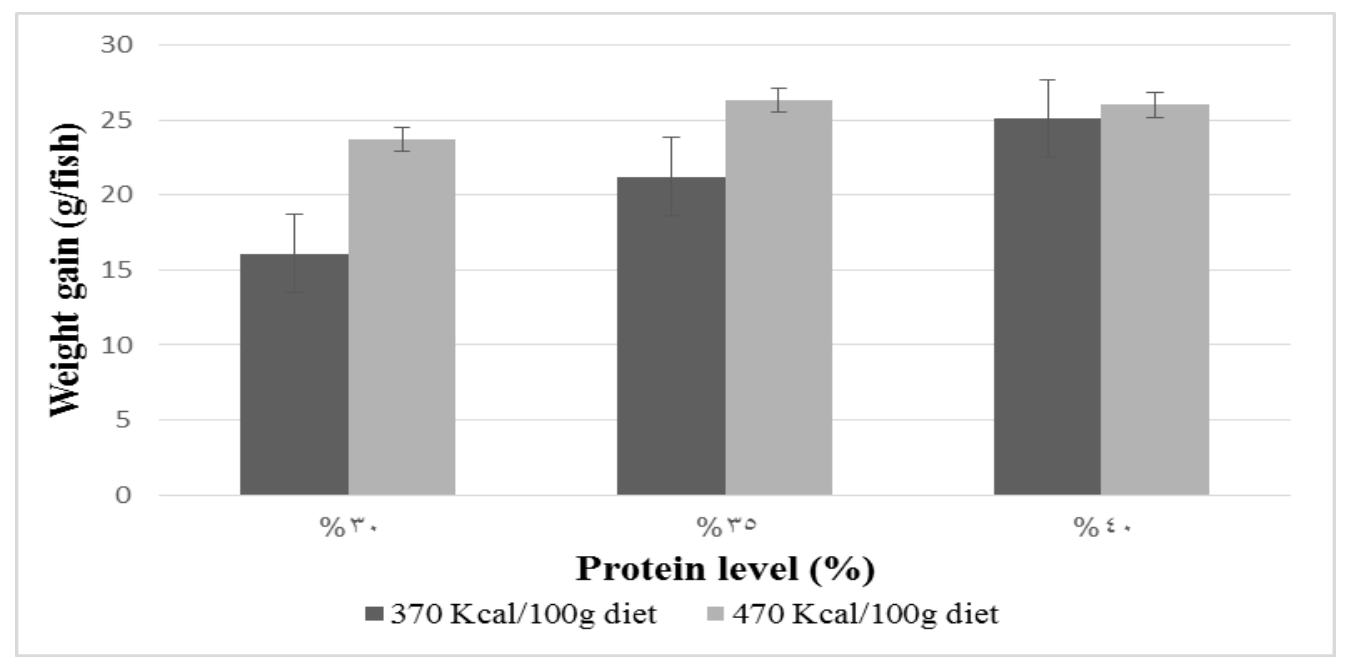

Fig. (1). Mean body weight gain of mono-sex $O$. niloticus fed three dietary protein and two energy levels.

The higher growth of mono-sex tilapia may have been due to the influence of methyl testosterone hormone used for sex-reversal, and has been shown to be a growth promoter in O. mossambicus (Kuwaye et al., 1993). Also, Hernandez et al. (2014) indicated that the faster growth of mono-sex tilapia might be due to the hormone used for the sex conversion and lack of energy expenditure in gonad maturation. Meanwhile, the specific growth rate (SGR \%) (Table 2) correspondingly revealed the same significant $(\mathrm{P}<0.05)$ fluctuated pattern as the FBW, WG, and ADG, as the highest SGR was observed for fry fed $35 \% \mathrm{CP}$; ME $470 \mathrm{Kcal} / 100 \mathrm{~g}$ diet, and the least was for $30 \% \mathrm{CP} ; 370 \mathrm{Kcal} \mathrm{ME} / 100 \mathrm{~g}$ diet. Despite of fry body weight in the present study, the SGR $(\%)$ was significantly higher for fry fed high levels of protein 
and energy than those fed low protein and energy levels. This corresponds with the findings of Hernandez et al. (2014) who found that the SGR (\%) value of mono-sex tilapia was significantly higher than that of mixed-sex tilapia. Although, the dietary protein levels in the present study had two energy levels (low and high), but the significant highest growth performance observed was with the high dietary protein and energy levels. On the contrary, Soltan et al. (2002) studied the effect of dietary energy level on average body weight, body length and condition factor, and their results showed that the final body weight, body length and condition factor significantly decreased with increasing dietary energy level from 300 to 330 and $360 \mathrm{kcal} \mathrm{ME} / 100 \mathrm{~g}$. In relation to high protein and energy levels, the fry survival (\%) (Table 2 and figure 2) was triggered significantly $(\mathrm{P}<0.05)$ and thus the $40 \% \mathrm{CP}$; $\mathrm{ME} 470 \mathrm{Kcal} / 100 \mathrm{~g}$ diet was reported to show the highest $(66 \%)$ survival which was $4.5 \%$ to $25 \%$ higher than all other treatments. Consequently, the final biomass (FBM/pond and FBM/feddan) of fry maintained significantly $(\mathrm{P}<0.05)$ the highest yield of fry (178kg/pond; $3560 \mathrm{~kg} / \mathrm{feddan})$ for diet with $40 \% \mathrm{CP}$; ME $470 \mathrm{Kcal} / 100 \mathrm{~g}$ diet, and the lowest was for $30 \% \mathrm{CP} ; 370 \mathrm{Kcal} \mathrm{ME} / 100 \mathrm{~g}$ diet (Table 2 and figure 3). However, in consistence to growth parameters the whole body protein and lipid contents tend to increase (not significantly) between treatments as the dietary protein and energy levels increase (Table 3).

However, feed conversion rate $(\mathrm{FCR})$ was significantly $(\mathrm{P}<0.05)$ enhanced when fry were fed $(40 \%$ $\mathrm{CP} ; 470 \mathrm{Kcal} \mathrm{ME} / 100 \mathrm{~g}$ diet) high protein and energy levels in winter. On the contrary, low protein and energy level $(30 \% \mathrm{CP} ; 370 \mathrm{Kcal} \mathrm{ME} / 100 \mathrm{~g}$ diet) feed in low temperature season for fry of O. niloticus induces fish to consume more feed, therefore, high FCR (Table 3) will be maintained to compensate their growth performance in such conditions. In agreement with Ahmed et al. (2004) that the significant variation in growth with dietary protein level could be due to the fluctuation of fish size, age, protein quality, stocking density, and hygiene and environmental condition which conceals the optimization of the growth parameters. Consequently, Ahmed et al. (2004) stated that the best growth and FCR for $O$. niloticus fry exhibited with $45 \%$ crude protein diet, while fingerlings and adult grow the same with 35

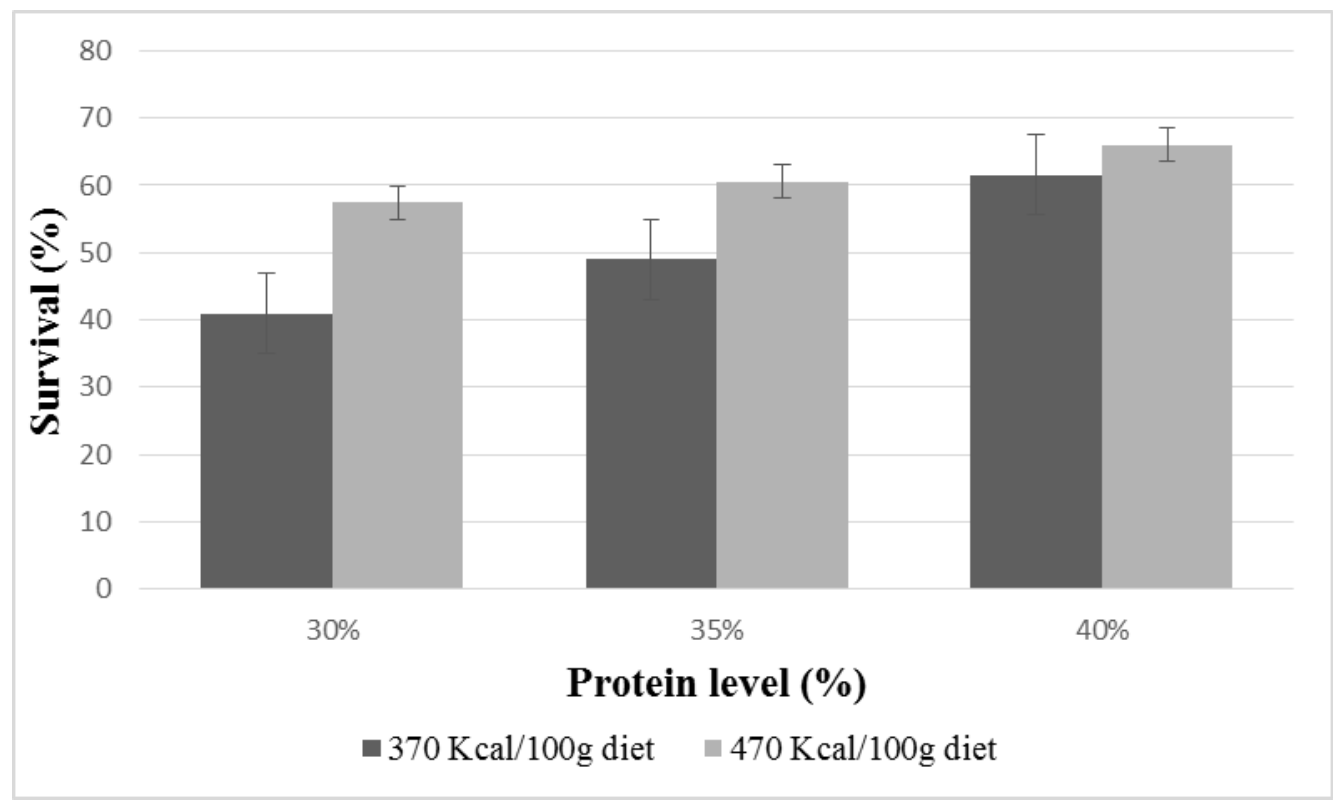

Fig. (2). Mean Survival of mono-sex $O$. niloticus fed three dietary protein and two energy levels. 


\section{Fayed}

Tables 2-3 
and $45 \%$ protein diets. In spite of the low temperature, the assessment of the FCR in the study herein denoted that it was enhanced with the increase of dietary protein and energy levels. However, Bahnasawy (2009) indicated similar findings with respect of the FCR where it decreased significantly with increasing dietary protein levels and the best FCR was obtained from $35 \%$ protein diet, while the poorest FCR was obtained by the lowest protein diet. With respect to FCR, the protein productive value (PPV) increased significantly with the increase of dietary protein and energy levels, and being the highest in fry fed with $40 \% \mathrm{CP} ; 470 \mathrm{Kcal} \mathrm{ME} / 100 \mathrm{~g}$ diet (Table 3). Although, the protein efficiency ratio (PER) was shown to increase with increasing dietary energy levels, but seems to decrease with the increase of dietary protein level (Table 3). With regard to the PER incurred in the present study that it significantly decreased with the increase of dietary protein and energy levels. The decrease of PER with increasing dietary protein level have also been reported by different authors for different tilapia species (Jauncey, 1982; Wee and Tuan, 1988; Shiau and Huang, 1989; Kheir, 1997; Ahmad et al., 2004; Bahnasawy, 2009). In support to the findings of the present study, Shimeno et al. (1981) reported that increasing dietary carbohydrate and fat caused a reduction in the activities of amino acid-degrading enzymes in the hepato-pancreas and resulted in reduction of nitrogen excretion rate and a high protein efficiency ratio. Nevertheless, the PPV values in the present study increased with increasing dietary protein and energy levels. Since the interaction between the dietary protein and energy levels positively enhanced the PPV of $O$. niloticus fry. Therefore, the protein to energy ration was considered to be optimum for fry and in turns had induced the growth of fry and triggered the fish to tolerate the low winter temperature. In support to the present study, Kaushik (1980) indicated that the effect of water temperature on apparent digestibility is the result of an effect of feed intake rather than an effect of water temperature itself. However, Cho and Kaushik (1990) presented that fish oil and plant oils (rapeseed, soybean, and linseed) were well digested (80-95\%) over a wide range of water temperatures $\left(5\right.$ to $\left.15^{\circ} \mathrm{C}\right)$. In the same manner, the constituent of the fish and plant oils in present study diets were 1:6 for the low energy and high energy diets, respectively. This explains the efficient utilization of the dietary protein with high dietary energy. In the present study a significant increase in muscle protein and decrease in lipid content of mono-sex fry of $O$. niloticus with increasing dietary protein level was detected. This relationship was also noticed by Dabrowski (1977) on grass carp, Jauncey (1982) on Sarotherodon mossambicus, Fah and Leng (1986) on guppy, Poecilia reticulata, Shiau and Huang (1989) on hybrid tilapia (O.niloticus x O.aureus), Wee and Tuan (1988), Kheir (1997), AlHafedh (1999) on Nile tilapia (O.aureus), and Bahnasawy (2009) on (O. niloticus). The increase in muscle protein and decrease in lipid content with increasing dietary protein levels could be attributed to the elevated carbohydrate level and low protein content in the diet of low protein level. The excess carbohydrate in the diet might trigger body fat storage (Fah and Leng, 1986). In accordance with the present study results, the high protein and energy levels appeared clearly to maintain the $O$. niloticus fry requirements to induce a better growth performance and survival rate throughout the winter in Egypt.

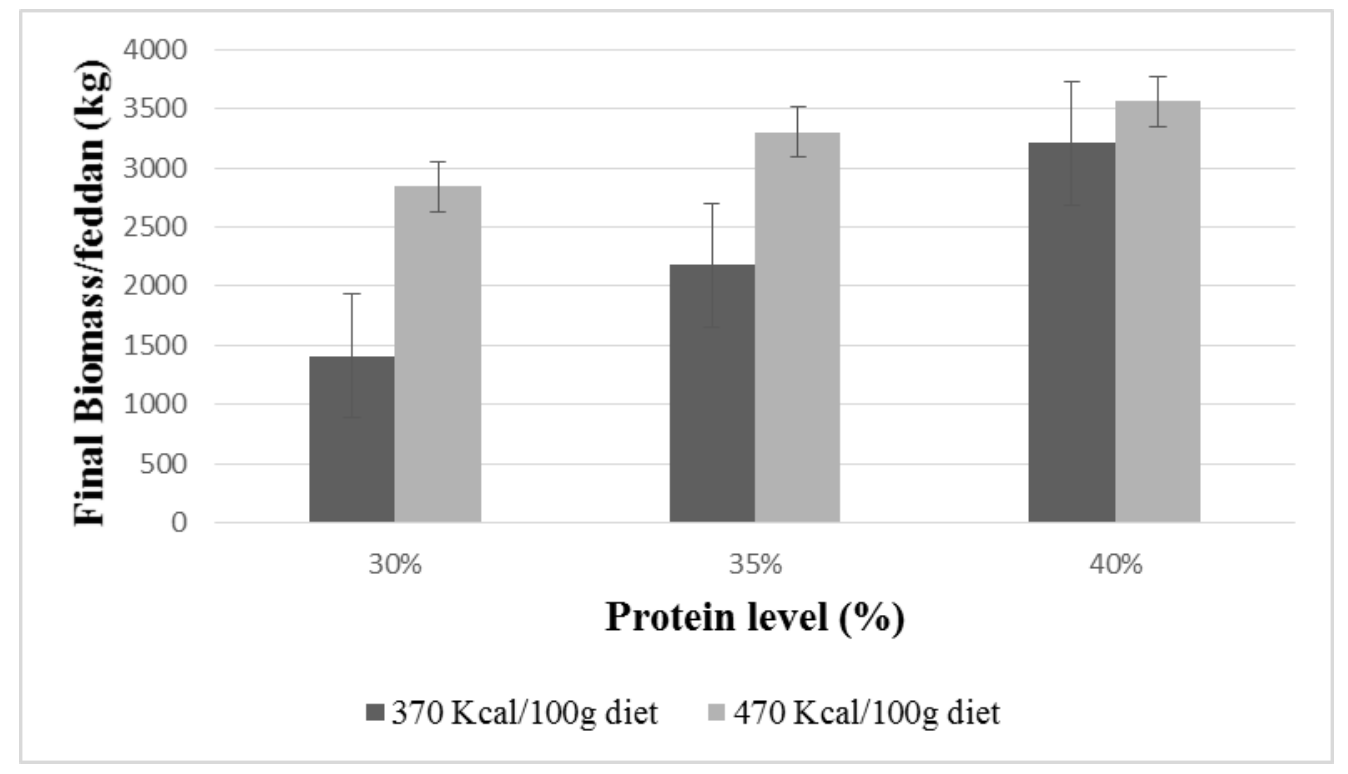

Fig. (3). Mean Final Biomass of mono-sex $O$. niloticus fed three dietary protein and two energy levels. 


\section{Fayed}

\section{CONCLUSION}

This study highlights the importance of protein and energy balance in diets offered to fry of $O$. niloticus in winter in order to tolerate the fluctuation of low temperatures and increase survival rate and growth performance throughout winter in Egypt.

\section{ACKNOWLEDGMENT}

The author would like to acknowledge Dr. Sallam, G.R., (Assistant Professor, National Institute of Oceanography and Fisheries, Egypt) for collaboration and unconditional support in the present study research.

\section{REFERENCES}

Ahmad, M.H.; M. Abdel-Tawwab and Y.A.E. Khattab (2004). Effect of dietary protein levels on growth performance and protein utilization in Nile tilapia (Oreochromis niloticus) with different initial body weights. The sixth international symposium on tilapia in aquaculture, Manila, Philippine.

Al Hafedh, Y.S. (1999). Effects of dietary protein on growth and body composition of Nile tilapia, Oreochromis niloticus L. Aquaculture Research, 30: 385-393.

AOAC (2000). Official Methods of Analysis, 17th ed. Association of Official Analytical Chemists, Gaithersburg, MD, USA.

Ashley, P.J. (2007). Fish welfare: Current issues in aquaculture. Applied Animal Behaviour Science, 104: 199-235.

Assaad, H.I; Y. Hou; L. Zhou; R.J. Carroll and G. Wu (2015). Rapid publication-ready MS-Word tables for two-way ANOVA. SpringerPlus, 4:33

Bahnasawy, M.H. (2009). Effect of Dietary Protein Levels on Growth Performance and Body Composition of Monosex Nile Tilapia, Oreochromis niloticus L. Reared in Fertilized Tanks. Pakistan Journal of Nutrition, 8: 674-678.

Ballarin, J.D. and R.D. Haller (1982). The intensive culture of tilapia in tanks raceways and cages. Croon Heln Ltd. London, pp: 265-266.

Behrends, L.L.; J.B. Kingsley and M.J. Bulls (1990). Cold tolerance in maternal mouth brooding tilapias: phenotypic variation among species and hybrids. Aquaculture 85, 271-280.

Caulton, M.S. (1982). Feeding, metabolism and growth of tilapias some quantitative considerations. pp. 157-184. In: Pullin R.S.V. and Lowe-McConnell R.H. (eds), The Biology and Culture of Tilapia. ICLARM, Manila, The Philippines.

Charo-Karisa, H.A.; M. Rezk; H. Bovenhuis and H. Komen (2005). Heritability of cold tolerance in Nile tilapia, Oreochromis niloticus, juveniles. Aquaculture, 249: 115 - 123.

Chervinski, J. (1982). Environmental physiology of tilapia. In: R.S.V., Lowe McConnell, H.R. Eds..The Biology and Culture of Tilapia. Pullin, ICLARM Conference Proceedings 7 International Centre for Living Aquatic Resources Management, Manila, Philippines, pp. 119-128, 432 pp.

Cho, C.Y. and S.J. Kaushik (1990). Nutritional energetics in fish: energy and protein utilization in rainbow trout (Salmo gairdneri). World Rev. Nutr. Diet., 61: 132-172.

Cruz, E.M.,and M. Ridha (1994). Over-wintering tilapia, Oreochromis spilurus (Gunther), fingerlings using warm underground sea water. Aquaculture and Fishery Management, 25: $865-871$.

Dabrowski, K. (1977). Protein requirements of grass carp Lovell, R.T., 1989. Nutrition and feeding of fish. Van fry (Ctenopharyngodon idella val.). Aquaculture, 12:63-73. 


\section{Egyptian J. Nutrition and Feeds (2015)}

Dan, N.C. and D.C. Little (2000). The culture performance of mono-sex and mixed-sex new-season and overwintered fry in three strains of Nile tilapia, Oreochromis niloticus, in northern Vietnam. Aquaculture, 184: 221-231

El-Sayed, A.F.M. (2006a). Tilapia culture. CABI Publishing, Oxfordshire.

El-Sayed, A.F.M. (2006b). Tilapia culture in salt water: Environmental requirements, nutritional implications and economic potentials. Eighth Symposium on Advances in Nutritional Aquaculture. November 15-17, Nuevo Leon, Mexico.

El-Sherif, M.S. and A.M. EL-Feky. (2008). Effect of ammonia on Nile Tilapia (O. niloticus) performance and some hematological and histological measures. Eighth International Symposium on Tilapia in Aquaculture. Cairo, Egypt.

Fah, S.K. and C.Y. Leng (1986). Some studies on the protein requirement of the guppy, Poecilia reticulate (Peters). J. Aquaricult. Aquatic Sci., 44: 1-12.

Fayed, W.M.; A.A. El-Dahhar; S.H. El-Zaeem; M.E. Salama; Z.A. EL-Greisy and G.R. Sallam (2015). Influence of protein levels and pond fertilization during broodstock pre-spawning period on the tolerance of Nile tilapia, Oreochromis niloticus, larvae to winter season temperature. Mediterranean Aquaculture Journal, (In press).

Fayed, W.M.A. (2015). Impact of Stocking Densities, Fertilization Regime and Dietary Protein Levels on Production and Profitability of Monosex Nile tilapia, Oreochromis niloticus, Cultured in Ponds. Egyptian Journal of Nutrition and Feeds, (In press).

GLOBALFISH. (2008). China loses tilapia in cold winter tilapia Market Report - May.

Hauser, W.J. (1977). Temperature requirement of Tilapia zillii. California Fish and Game, 63: 228-233.

Hernández, M.; E. Gasca-Leyva and A. Milstein (2014). Polyculture of mixed-sex and male populations of Nile tilapia (Oreochromis niloticus) with the Mayan cichlid (Cichlasoma urophthalmus). Aquaculture, 418-419, 26-31.

Hsieh, S.L.; C.Y. Hu; Y.T. Hsu and T.J. Hsieh (2007). Influence of dietary lipids on the fatty acid composition and stearoyl-CoA desaturase expression in hybrid tilapia (Oreochromis niloticus $\times O$. aureus) under cold shock. Comparative Biochemistry and Physiology, Part B 147 (2007) 438-444

Jauncey, K.L. (1982). The effect of varying dietary protein level on growth, food conversion protein utilization and body composition of juvenile tilapia (Sarotherodon mossambicus). Aquacult., 27: 4354.

Jauncey. K. (2000). Nutritional requirements. P. 327-375. In: M.C.M. Beveridge and B.J. McAndrew (eds.) Tilapias: Biology and Exploitation, Fish and Fisheries Series 25, Kluwer Academic Publishers, Dordrecht, The Netherlands.

Jiazhao, L. (1991). Tilapia. In: Lin, Z. Ed., Pond Fisheries in China. International Academic Publishers, Beijing, China, pp. 161-166.

Kamel, E.A.; H.A. Elghobashy and M.A. Farag (2008). Performance of growth and survival rates of Oreochromis aureus juveniles during hard winter condition in Egypt. $8^{\text {th }}$ International Symposium on Tilapia in Aquaculture, 319-327.

Kaushik S.J. (1980). In “Aquaculture in Heated Effluents and Recirculated Systems” (K. Tiews, ed.), Vol. I, pp. 77-89. Heenemann GmbH, Berlin.

Kenawy, S.M. (1993). Performance of food organisms and tested diets in fish nursing. J. Intern. Fish. Soc. India, 25(1): 39-41.

Kheir, M.T. (1997). Growth of Oreochromis niloticus (Linnaeus, 1758) raised on feeds with different protein levels. Egypt. J. Zool., 28: 65-76.

Kuwaye, T.T.; D.K. Okimito; S.K. Shimoda; R.D. Howeiton; L. Hoa-Ren; P.K.T. Pang; and E.G. Grau (1993). Effect of 17 -methyl testosterone on the growth of euryhaline tilapia Oreochromis mossambicus, in fresh water and sea water. Aquaculture, 113: 137-157.

Likongwe, J.S.; T.D. Stecko; J.R. Stauffer and R.F. Carline (1996). Combined effects of water temperature and salinity on growth and feed utilization of juvenile Nile tilapia Oreochromis niloticus (Linneaus). Aquaculture, 146: 37-46. 
Lovshin, L.L.; A.B. De-Silva; A. Cameiro-Sobrinho and F.R. Melo (1990). Effects of Oreochromis niloticus females on the growth and yield of male hybrids (O. niloticus female x $O$. hormonrun male) cultured in earthen ponds. Aquaculture, 88: 55-60.

Mires, D. (1995). The tilapias. pp. 133-152. In: Production of Aquatic Animals: Fishes (eds Nash, C. E., and A. J. Novotony. Elsevier, New York.

Mjoun, K.; K.A. Rosentrater and M.L. Brown (2010). Tilapia: Environmental Biology and Nutritional Requirements. USDA-Agricultural Research Service, South Dakota State University. Publication article No. FS963-02

Philippart, J.Cl. and J.C.1. Ruwet (1982). Ecology and distribution of tilapias. In: Pullin, R.S.V., Lowe McConnell, H.R. Eds., The Biology and Culture of Tilapia. ICLARM Conference Proceedings 7 International Centre for Living Aquatic Resources Management, Manila, Philippines, pp. 15-59, 432 pp.

Ross, L.G. (2000). Environmental physiology and energetics. pp. 89-128. In: M. C. M. Beveridge and B. J. McAndrew (eds.) Tilapias: Biology and Exploitation, Fish and Fisheries Series 25, Kluwer Academic Publishers, Dordrecht, The Netherlands.

Shamsuddin, M.; M.B. Hossain; M.M. Rahman; M. Asadujjaman and M.Y. Ali (2012). Performance of Monosex Fry Production of Two Nile Tilapia Strains: GIFT and NEW GIPU. World Journal of Fish and Marine Sciences, 4 (1): 68-72.

Shiau, S.Y. and S.L. Huang (1989). Optical dietary protein level for hybrid tilapia (0. niloticus x O. aureus) reared in seawater. Aquaculture, 81: 119-127.

Shimeno, S.; M. Takeda; S. Takayama and H. Sasaki (1981). Response of nitrogen excretion to change of dietary composition in carp. Bull. Japan. Soc. Sci. Fish, 47: 191-195.

Siddik, M.A.; A. Nahar; F. Ahamed; Md.Y. Hossain (2014). Over-wintering growth performance of mixed-sex and mono-sex Nile tilapia Oreochromis niloticus in northeastern Bangladesh. Croatian Journal of Fisheries, 72: 70-76.

Soltan, M.A.; A.A. Radwan and I.M. Samra (2002). Effect of varying protein, energy and protein to energy ratio on growth, feed efficiency and body composition of Nile tilapia, Oreochromis niloticus. The 1st Annual Conference of the Egyptian Aquaculture Society, Al-Aresh, North Sinai, Egypt, 13-15 December.

Wee, K.L. and N.A. Tuan (1988). Effects of dietary protein level on growth and reproduction in Nile tilapia (Oreochromis niloticus). ICLARM Conference Proceedings, 15: 623.

Williams, B. and S. Dasgupta (2007). Economics of Micro-Scale Tilapia (Oreochromis aureus) Processing in Kentucky's Mobile Processing Unit (MPU) Kentucky Aquatic Farming, Vol. 20, no. 1. 
Egyptian J. Nutrition and Feeds (2015)

تحسين إنتاجية زريعة البلطي النيلي وحيد الجنس أثناء انخفاض درجات الحراره في موسم الثتاء

وليد محمد عبد الوهاب محمد فايد

قسم الإتتج الحيوانى والسمكى، كليه زراعة سابا باشا، جامعة الإسكنلايه، ج. م.ع

أجريت هذه التجربه بهدف الحصول على إصبعيات بلطى نيلى تكفى لبداية موسم إنتاج جديد تتمتع بحيويه ونمو جيد بعد بلدي تخزينها

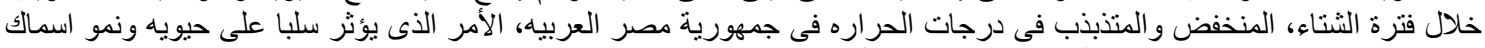

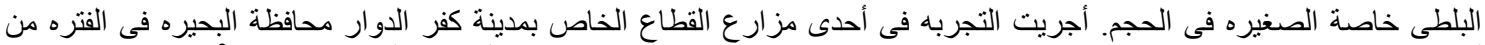

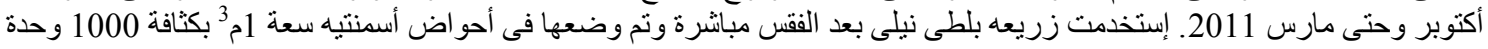

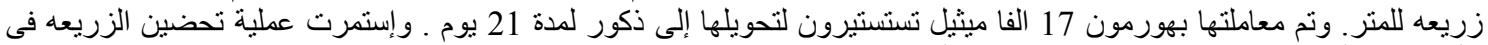

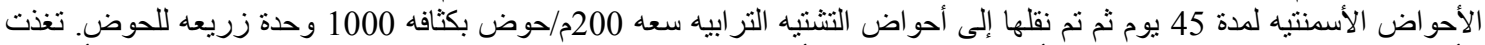

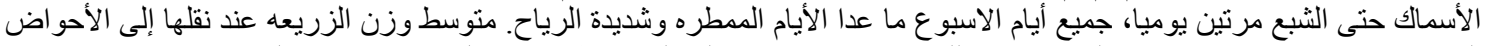

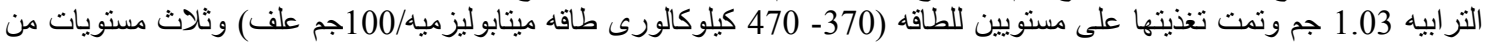

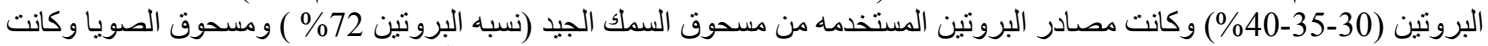

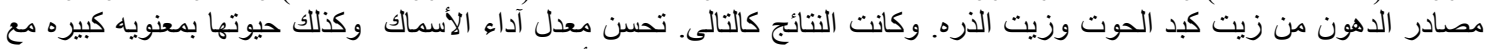

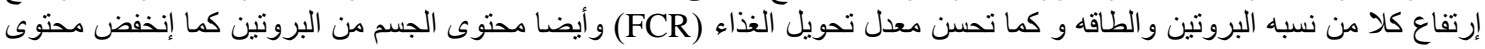

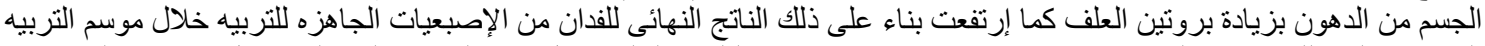

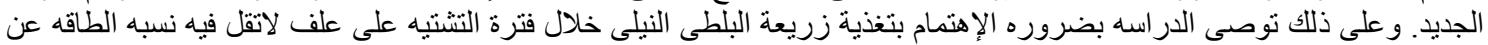

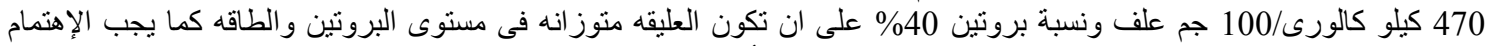

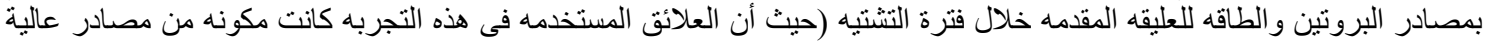
الجوده من البروتين و الطاقة) لتتكمن من تحمل التنبب الحادث فى درجة الحر اره خلال موسم الثناء. 
Table (2). Means ( \pm Standard Error Mean) of final body weight (FBW, g/fish), weight gain (WG, g/fish), average daily gain (ADG, g/fish/day), average daily gain percentage (\%), specific growth rate (SGR, \%), final biomass (FBM, kg/pond and /feddan), and survival rate (SUR, \%) for fry of mono-sex $O$. niloticus in the present study.

\begin{tabular}{|c|c|c|c|c|c|c|c|c|c|}
\hline \multirow{2}{*}{ Variable } & \multicolumn{3}{|c|}{$370 \mathrm{Kcal} / 100 \mathrm{~g}$ diet } & \multicolumn{3}{|c|}{$470 \mathrm{Kcal} / 100 \mathrm{~g}$ diet } & \multicolumn{3}{|c|}{$P$-value } \\
\hline & $30 \%$ & $35 \%$ & $40 \%$ & $30 \%$ & $35 \%$ & $40 \%$ & F1 & $\mathrm{F} 2$ & $\mathrm{~F} 1 \times \mathrm{F} 2^{1}$ \\
\hline FBW & $17.1 \pm 1.4^{\mathrm{c}}$ & $22.2 \pm 0.3^{b}$ & $26.1 \pm 0.2^{\mathrm{a}}$ & $24.7 \pm 0.2^{\mathrm{ab}}$ & $27.3 \pm 0.4^{\mathrm{a}}$ & $27 \pm 0.5^{\mathrm{a}}$ & $<0.001$ & $<0.001$ & 0.006 \\
\hline WG & $16.1 \pm 1.4^{\mathrm{c}}$ & $21.2 \pm 0.3^{\mathrm{b}}$ & $25.1 \pm 0.2^{\mathrm{a}}$ & $23.7 \pm 0.2^{\mathrm{ab}}$ & $26.3 \pm 0.4^{\mathrm{a}}$ & $26 \pm 0.5^{\mathrm{a}}$ & $<0.001$ & $<0.001$ & 0.006 \\
\hline $\mathrm{ADG}$ & $0.09 \pm 0.01^{\mathrm{c}}$ & $0.12 \pm 0.002^{\mathrm{b}}$ & $0.14 \pm 0.001^{\mathrm{a}}$ & $0.13 \pm 0.001^{\mathrm{ab}}$ & $0.15 \pm 0.002^{\mathrm{a}}$ & $0.14 \pm 0.003^{\mathrm{a}}$ & $<0.001$ & $<0.001$ & 0.006 \\
\hline $\mathrm{ADG} \%$ & $8.67 \pm 0.76^{\mathrm{c}}$ & $11.4 \pm 0.16^{\mathrm{b}}$ & $13.5 \pm 0.11^{\mathrm{a}}$ & $12.8 \pm 0.11^{\mathrm{ab}}$ & $14.2 \pm 0.22^{\mathrm{a}}$ & $14 \pm 0.27^{\mathrm{a}}$ & $<0.001$ & $<0.001$ & 0.006 \\
\hline SGR $\%$ & $1.56 \pm 0.05^{\mathrm{c}}$ & $1.71 \pm 0.01^{\mathrm{b}}$ & $1.8 \pm 0.004^{\mathrm{ab}}$ & $1.77 \pm 0.005^{\mathrm{ab}}$ & $1.82 \pm 0.01^{\mathrm{a}}$ & $1.81 \pm 0.01^{\mathrm{ab}}$ & $<0.001$ & 0.001 & 0.009 \\
\hline FBM/pond & $70.4 \pm 9.16^{\mathrm{d}}$ & $109 \pm 0.75^{\mathrm{c}}$ & $161 \pm 5.14^{\mathrm{ab}}$ & $142 \pm 7.33^{\mathrm{b}}$ & $165 \pm 1.67^{\mathrm{ab}}$ & $178 \pm 6^{\mathrm{a}}$ & $<0.001$ & $<0.001$ & 0.009 \\
\hline FBM/feddan & $1410 \pm 183^{d}$ & $2180 \pm 15^{\mathrm{c}}$ & $3210 \pm 103^{a b}$ & $2840 \pm 146^{b}$ & $3300 \pm 33.5^{\mathrm{ab}}$ & $3560 \pm 120^{\mathrm{a}}$ & $<0.001$ & $<0.001$ & 0.009 \\
\hline SUR \% & $41 \pm 2^{\mathrm{c}}$ & $49 \pm 1^{\mathrm{bc}}$ & $61.5 \pm 1.5^{\mathrm{a}}$ & $57.5 \pm 2.5^{\mathrm{ab}}$ & $60.5 \pm 1.5^{\mathrm{a}}$ & $66 \pm 1^{\mathrm{a}}$ & $<0.001$ & $<0.001$ & 0.031 \\
\hline
\end{tabular}

Values are means \pm SEM, $n=2$ per treatment group

${ }^{a-d}$ Means in a row without a common superscript letter differ $(P<0.05)$ as analyzed by two-way ANOVA and the TUKEY test.

${ }^{1} F 1 \times F 2=$ Factor $A \times$ Factor $B$ interaction effect.

Table (3). Means ( \pm Standard Error Mean) of body protein (g/fish), body lipid (g/fish), feed conversion ratio (FCR), protein productive value (PPV), and protein efficiency ratio (PER) for fry of mono-sex $O$. niloticus in the present study.

\begin{tabular}{|c|c|c|c|c|c|c|c|c|c|}
\hline \multirow{2}{*}{ Variable } & \multicolumn{3}{|c|}{$370 \mathrm{Kcal}$} & \multicolumn{3}{|c|}{$470 \mathrm{Kcal}$} & \multicolumn{3}{|c|}{$P$-value } \\
\hline & $30 \%$ & $35 \%$ & $40 \%$ & $30 \%$ & $35 \%$ & $40 \%$ & F1 & $\mathrm{F} 2$ & $\mathrm{~F} 1 \times \mathrm{F} 2$ \\
\hline protein & $15.6 \pm 0.5$ & $17.6 \pm 0.5$ & $17.8 \pm 0.5$ & $15.7 \pm 0.5$ & $17.8 \pm 0.5$ & $18.4 \pm 0.5$ & 0.529 & 0.006 & 0.87 \\
\hline lipid & $7.71 \pm 0.04$ & $6.45 \pm 0.5$ & $6.54 \pm 0.5$ & $7.95 \pm 0.04$ & $7.91 \pm 0.04$ & $6.49 \pm 0.04$ & 0.058 & 0.011 & 0.084 \\
\hline FCR & $1.77 \pm 0.03^{\mathrm{a}}$ & $1.47 \pm 0.03^{b}$ & $1.33 \pm 0.002^{\mathrm{cd}}$ & $1.42 \pm 0.015^{\mathrm{bc}}$ & $1.25 \pm 0.02^{\mathrm{d}}$ & $1.23 \pm 0.02^{\mathrm{d}}$ & $<0.001$ & $<0.001$ & 0.003 \\
\hline PPV & $8.5 \pm 0.5^{\mathrm{c}}$ & $19.9 \pm 0.5^{\mathrm{b}}$ & $21.6 \pm 0.5^{\mathrm{b}}$ & $7.38 \pm 0.5^{\mathrm{c}}$ & $24.7 \pm 0.5^{\mathrm{a}}$ & $26.7 \pm 0.5^{\mathrm{a}}$ & $<0.001$ & $<0.001$ & 0.001 \\
\hline PER & $2.2 \pm 0.06^{\mathrm{ac}}$ & $2.15 \pm 0.06^{b c}$ & $1.97 \pm 0.06^{\mathrm{c}}$ & $2.49 \pm 0.06^{\mathrm{a}}$ & $2.39 \pm 0.06^{\mathrm{ab}}$ & $2.1 \pm 0.06^{\mathrm{bc}}$ & 0.003 & 0.003 & 0.373 \\
\hline
\end{tabular}

Values are means $\pm S E M, n=2$ per treatment group.

${ }^{a-c}$ Means in a row without a common superscript letter differ $(P<0.05)$ as analyzed by two-way ANOVA and the TUKEY test.

${ }^{I} F 1 \times F 2=$ Factor $A \times$ Factor B interaction effect. 